\title{
論文特集「超微粒子の化学とその応用」
}

（日本化学会誌，1984，（6 ）, p.998～1004）

(C) 1984 The Chemical Society of Japan

\section{シリカ担持ロジウム触媒のロジウム粒子 の粒径制御とその触媒作用}

\author{
（1983 年 10 月 4 日受理）
}

高崎誠司 ${ }^{* *}$ ・古賀文雄 ${ }^{* * *} \cdot$ 田辺秀二・上野晃史*・小寺嘉秀

硝酸ロジウムのエチレングリコール溶夜とケイ酸テトラエチルを混合し，加水分解するとゲルが得ら れる。このゲル中には Rh-O-Si 構造が存在し，この構造はゲルを乾燥，筅成しても保持されている。 水素還元によりこの構造が崩壊し，金属ロジウムが析出する。金属ロジウム粒子の粒径は触媒中のロジ ウム濃度により制御され，粒径の分布はシャープで均一な粒径を有するロジゥム金属が析出しているこ とを確かめた。

ロジウム濃度を $0.34 \mathrm{wt} \%$ から $6.89 \mathrm{wt} \%$ まで变化させ，各種の粒径を有する $\mathrm{Rh} / \mathrm{SiO}_{2}$ 触媒を製造 した。モデル反応として 1-プロパノールの分解反応を選び，ロジウム粒子の粒径と反応の比活性との 関連性について検討した。ロジウム粒子の粒径が 30〜 $40 \AA ̊$ より小さくなると, 比活性がいちじるしく 增大することを見いだした。ロジウム粒子が微結晶体であると考劣ると，粒子の微少化とともに結晶の 辺部や頂点部に位置するロジウム原子数が増大することから，1-プロパノールの分解反応には辺部や頂 点部に位置するロジウム原子が重要な役割をるっていると考えた。プロピオンアルデヒドを $\mathrm{Ni} / \mathrm{SiO}_{2}$ 触媒上で分解すると，その分解反応はニッケル結晶体の平面部に位置する原子上で進行することがわか っている。したがって，口ジウム触媒でも同様な機構であると考党ると，1-プロパノールは，口ジウム 粒子の辺部や頂点部に吸着し，吸着アルデヒドを生成するが，この吸着アルデヒドが，平面部に位置す るロジウム原子上に移動して分解されると結論できる。

\section{1 緒言}

鉄やニッケルなどの遷移金属元素はその最外殼に $\mathrm{d}$ 電子を有し て和り，これらの金属を触媒として用いる場合にはその触媒作用 はd電子のエネルギー状態と無関係ではない。金属粒子では金属 結合生成のため， $\mathrm{d}$ 電子の一部がよりエネルギー準位の高い $\mathrm{S}$ 軌 道に励起するために，いわゆる $\mathrm{d}$ 電子孔が生成されるがこれが触 媒作用と強く関連しているといら説もある1)。金属の物性と触媒 作用の相関性は金属の d 電子エネルギー準位が連続帯であること を前提に検討されたが，厳密には金属粒子を構成する金属原子数 を $N$ とすると $N$ 個のエネルギー準位が存在し，各準位間の間隔は $\varepsilon_{\mathrm{F}} / N$ のオーダーである。ここで, $\varepsilon_{\mathrm{F}}$ はその金属の Fermi エネ ルギーを示している。粒子が大きいときには $N$ が大きくなり，乙 たがって準位間隔 $\varepsilon_{F} / N$ はほとんど 0 となり連続帯近似が成立す る。しかし，粒子が極端に小さくなると準位間隔 $\varepsilon_{\mathrm{F}} / N$ は有限の

豊橋技術科学大学, 440 豊橋市天伯町字雲往ヶ丘

** 現在 川研ファインケミカルズ株式会社, 356 川越市今福 中台

*** 現在 菱化工業株式会社, 712 倉敷市広江

1）この説は Discuss. Faraday Soc., 8 (1950) 飞特集され ており，Beeck の研究 (p.118)，Vogt の研究 (p. 172) および Dowden と Reynolds の研究 (p.184) などが報 告されている。
值をむつようになり，連続帯がしだいに離散的となる。たとえ

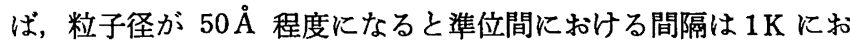
ける $k T$ と同程度となり，極低温では熱的励起も制限されるよう になる。このことを最初に理論的に解析したのは久保2)である。 久保理論によれば $50 \AA$ 程度の超微粒子の電子状態は bulk の金 属の電子状態とは明らかに異なったものになる。電子状態の相違 は触媒作用にも反映されるはずであるといらことから超微粒子の 触媒作用に関する研究がさかんに行なわれるようになった。

$\mathrm{McKee}^{3)}$ は白金触媒上におけるプロパンのクラッキング反応 で，単位白金表面積あたりの活性（以下比活珄という）は白金粒 子の微少化とともに増大寸ること，および反応の活性化ェネルギ 一も白金粒子の微少化とともに減少することを見いだした。ま た，シリカーアルミナに担持したニッケル触媒上でのエタンの水 素化分解反応 ${ }^{4}$ や白金触媒上でのシクロヘキサン類の水素化分解 反応"地活性も，それぞれニッケル粒子径や白金粒子径の減少 にともない増大することも報告された。一方，プロパンの酸化反

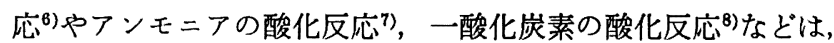

2) R. Kubo, J. Phys. Soc. Jpn., 17, 975(1962).

3) D. W. McKee, J. Phys. Chem., 67, 841(1963).

4) J. L. Carter, J. A. Cusumano, J. H. Sinfelt, ibid., 70, 2257(1966).

5) J.R. Anderson, Y. Shimoyama, Proc. 5 th Intern. Congr. on Catalysis, Miami (1972). 
白金粒子径の增大とともにその比活性も增大すると報告されてい る。

このように金属粒子の粒径が比活性の増減と関連している反応 が数多く見いだされているが，この原因は金属粒子の表面構造が 微粒子化により変化するためであると考兵た Boudart $\left.{ }^{9}\right)$ は，これ らの反応は表面構造の变化に敏感に対応する反応であるとして, structure sensitive reaction と命名した。もちろん, 表面構造 の変化に鈍感な反応もあり，二酸化硫黄10) 户水素11)の酸化反応な どは白金触媒上の白金粒子の大小関係なく，つね机同し比活性 を示すことが知られている。このような反応は structure insensitive reaction と呼ばれている。

それでは表面構造の変化とは具体的にはどのようなことである らか。van Hardveld ら ${ }^{12}$ は単結晶の表面に配列している原子は その配位数により 3 種にわけられ，単結晶の大きさによりそれぞ れの原子の存在割合が変わることを示した。3 種の原子とは単結 晶の結晶面に位置する原子, 辺部位置する原子および頂点部に 位置する原子であり,この順に配位数が減少する。単結晶の大き さが $50 \AA ̊$ より小さくなると辺部や頂点部に位置する原子の存在 割合いがいちじるしく增大する。触蝶反応は金属粒子の表面で進 行すると考兄られるから（粒子が単結晶として存在すると仮定す ると), 粒子表面に存在する配位数の異なる原子の存在割合はと のまま触媒性能に関係するであろら。

LePage ら 18)はシリカに担持した白金触媒上のペンタンの水素 化分解反応の比活性は白金粒子の微少化とともに増大し, その異 性化反応は粒子径の微少化とともに減少することから, 水素化分 解反応は白金微結晶の辺部や頂点部に位置した白金原子上で，ま た異性化反応は結晶面上に配列した白金原子上で進行すると結論 した。

Somorjai ら (4)は結晶表面には平らな面（テラス）だけでなく ステップやキンクなどの不規則構造も存在することに着目し, 白 金単結晶の $(1,1,1),(5,5,7),(10,8,7)$ および $(25,10,7)$ の 4 種の結晶面上でのへプタンの環化脱水素および水素化分解につい て検討した。(1, 1, 1) 面上ではテラス構造が多いのに対し（25, $10,7)$ 面ではステップやキンク構造が多く, $(5,5,7)$ 面や $(10$, $8,7)$ 面では両者が混在している。へプタンの環化脱水素反応は これらの面のらち $(5,5,7)$ 面や $(10,8,7)$ 面ですみやかに進行 し, $(1,1,1)$ 面や $(25,10,7)$ 面では水素水分解反応が進行した。 このことから，ヘプタンの環化脱水素反応にはテラスのみならず

6) 所 康夫, 㻕 和美, 楖良 蝵, 内島俊雄, 米田幸夫, 日 化, 1979, 1646.

7) J. J. Ostermair, G. R. Katzer, W. H. Manogue, $J$. Catal., 33, 457(1974).

8) P. H. Otero-Schipper, W. A. Wachter, J.B. Butt, R. L. Burwell, Jr., J. B. Cohen, ibid., 53, 414(1978).

9) M. Boudart, Adv. Catal., 20, 153(1969).

10) G. K. Boreskov, V.S.Chesalova, Zh. Fiz. Khim., 30, 2(1956).

11) G. K. Boreskov, M. G. Slinko, V. S. Chesalova, ibid., 30, 2787(1956).

12) Van Hardeveld, van Montfoort, Surf. Sci., 4, 396 (1964).

13) J. P. Brunelle, A. Sugier, J. F. LePage, J. Catal., 43, 273(1976).

14) W.D.Gillespie, R. K. Herz, E. E. Petersen, G. A. Somor jai, ibid., 67, 371(1981); 70, 147(1981).
ステップやキンク構造の存在も必要であり，おそらくへプタンは ステップやキンク構造部に吸着, 活性化されたのちテラス部に移 動して環化脱水素されるであろらと推定された。

このように, 微粒子化にともなら比活性の增減は触媒上の金属 粒子の表面構造の変化に起因するといら意見に対し, 微粒子化に よる金属粒子の電子的性質の变化も無視できないとする意見むあ る。Primet ら ${ }^{15}$ はアルミナに担持した白金触媒上での一酸化窒 素の吸着状態を赤外吸収スペクトルで検討したところ, 白金粒子 の微少化とともに吸着一酸化窒素の赤外吸収帯が高波数側にシフ トすることを見いだした。このことは白金粒子は微少化するにつ れて, アルミナ担体に電子を流出し, 陽イオン性を帯びてくるこ とを示している。また，高須ら ${ }^{18)}$ む UPS (He(II)) を用いた実 験から，20〜30Å より小さな $\mathrm{Pd}$ 粒子は金属といらよりむしろ 原子状パラジウムの性質を示すと報告している。

本研究ではシリカに担持したロジウム触媒のロジウム粒子の粒 子径を制御する方法について検討するとともに, その粒子径が 1ープロパノールの分解反応にどのよらに影響するかについても検 討した。

\section{2 実験}

\section{1 触媒の調製}

本研究に用いた $\mathrm{Rh} / \mathrm{SiO}_{2}$ 触媒はケイ酸テトラェチルなどを用 いたアルコキシド法17)で調製した。すなわち，硝酸ロジウム（キ

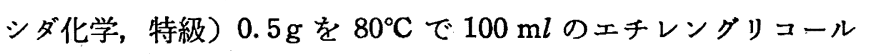
(キシダ化学, 特級) に溶解し, この所定量を $50 \mathrm{ml}$ のケイ酸テ トラエチル (キシダ化学, 特級) と混合する。この混合溶液を $80^{\circ} \mathrm{C}$ で 5 時間加熱かきまぜたのち室温まで放冷し，はげしくか きまぜながら $200 \mathrm{~m} l$ の蒸留水を滴下する。そのまま一晚かきま ぜつづけると溶夜はゲル状になる。もし, ゲルの生成が達い場 合には $10 \%$ アンモニア水 $5 \mathrm{~m} l$ を滴下しゲル化を促進してもよ い。このよらにして得られたゲルを沪過し, 蒸留水で十分に洗浄 したのち、ロータリーエパポレーターで減圧乾燥する。さらに乾 燥器中で十分に翰燥し, 空気中 $450^{\circ} \mathrm{C} て ゙ ~ 4$ 時間焼成する。これを 触媒として使用するさいには, 所定量を反応器中に充填したのち $450^{\circ} \mathrm{C}$ で 2 時間, 水素により還元する。触媒中の口ジウム濃度 は，硝酸ロジウムのエチレングリコール溶液とケイ酸テトラェチ ルの混合比により調整することができる。

一般にケイ酸テトラェチルのゲル化速度は遅いので, エチレン グリコールや硝酸ロジゥム中に含まれる水分の除去は大して重要 ではない。

\section{2 触媒中のロジウムの存在樣式と粒子径の測定}

焼成後の触媒中のロジゥムの存在様式を検討するため, $\mathrm{KBr}$ 錠剂法により，赤外吸収スペクトルを測定した（日本分光製 A2 型)。

還元後の触媒中の口ジウム粒子の粒径は透過型電子顕微鏡（日 立製，H-300）および水素による化学吸着法で測定した。透過型

15) M. Primet, J. M. Basset, E. Garbowski, M. V. Mathieu, J. Am. Chem. Soc., 97, 3655(1975).

16) Y. Takasu, R. Unwin, B. Tesche, A. M. Bradshaw, M. Grunze, Surf. Sci., 77, 219(1978).

17) A. Ueno, H. Suzuki, Y. Kotera, J. Chem. Soc., Faraday Trans. 1, 79, 127(1983). 


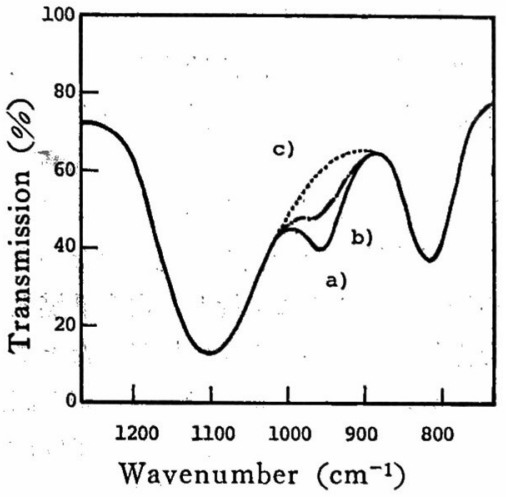

Fig. 1 IR spectra of $\mathrm{Rh} / \mathrm{SiO}_{2}$ catalyst
a) : Prepared by alkoxide technique
b) : After reduction by hydrogen
c) : Prepared by impregnation method

電子顕微鏡による観察では，触媒を乳鉢ですりつぶしたのち超音 波によりェタノール中に分散させ，分散液の一部をコロジオン膜 付のメッシュ（日新 E M製，400メッシュ）飞滴下し，乾燥した のちに観察した。 5 万倍で撮影したのち $2 \sim 4$ 倍に引きのばし， 写真上から 300 500 個の粒子の粒径を測定し粒径分布曲線を求 めた。ロジウム濃度が $2 \mathrm{wt} \%$ 以下の触媒ではロジウム粒子の粒 径が小さく，顕微鏡による測定は困難であった。

水素の化学吸着による平均粒子径の測定では, 内容積約 $100 \mathrm{~m} l$ のガラス製反応系に約 $0.3 \mathrm{~g}$ の触媒を充填し， $450^{\circ} \mathrm{C} て ゙ 2$ 時間水 素で還元後その温度で 2 時間排気し, 排気をつづけながら室温ま で放冷した。つぎに水素ガスを導入し，バラトロン圧力測定器 (MKS, 222 B) により 5〜50 mmHg の圧力範囲で四着量と四着 平衡圧を求めたのち, 圧力 0 亿外插した值を用いてロジウムの表 面積や平均粒子径を算出した ${ }^{18)}$ 。平均粒子径の算出にさいして は， ロジウム粒子は立方体の形で存在すると仮定し， $\bar{d}=5 / \rho \cdot S$ を用いた。ここで，Sはロジウムの比表面積であり， $\rho$ は金属口 ジウムの密度 $\left(12.4 \mathrm{~g} / \mathrm{cm}^{3}\right)$ である。なお, 吸着実験に用いた水 素ガスは純度が 99.9999\% (日本酸素製) の高純度市肘ガスであ る。

\subsection{1-プロパノールの分解反応}

内容積 $600 \mathrm{~m} l$ の閉鎖循環系反応装置に約 $0.3 \mathrm{~g}$ の触媒を充填 し, 約 $600 \mathrm{mmHg}$ の水素がスを導入し $450^{\circ} \mathrm{C} て ゙ 2$ 時間還元した。 還元中は循環装置の一部を液体窒素で冷却し，生成する水をトラ ップした。還元終了後, 所定の反応温度にまで冷却し, 通常 13 $\mathrm{mmHg}$ の 1-プロパノール蒸気を導入して反応を行なった。反応 により生成したガスは，直列に直結した 2 台のガスクロマトグラ フに導入し, エチレン, エタンなどの炭化水素は Polapak Q に よりまた，メタン，水素，一酸化炭素は Molecular sieves 13 Xにより定量した。1-プロパノールの分解反応速度は, 反応開始 後 10 15 分間に生成する一酸化炭素の量から求めた。各触媒上 のロジゥムの表面積はわかっているので, 反応速度は turnover frequency (CO molecules $/ \mathrm{s} \cdot \mathrm{m}^{2} \mathrm{Rh}$ )を用いて示した。

18) G. R.Wilson, W. K. Hall, J. Catal., 17, 190(1970); E. Kikuchi， K. Ito, T. Ino, Y. Morita, ibid., 46, 382 (1977).

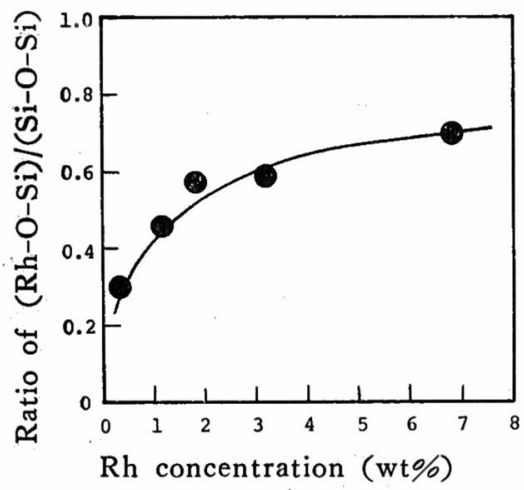

Fig. 2 Change in the IR absorption intensity ratio of $(\mathrm{Rh}-\mathrm{O}-\mathrm{Si})$ to $(\mathrm{Si}-\mathrm{O}-\mathrm{Si})$ with the $\mathrm{Rh}$ concentration

a) 3.04 wto $\mathrm{Rh} / \mathrm{SiO}_{2}$

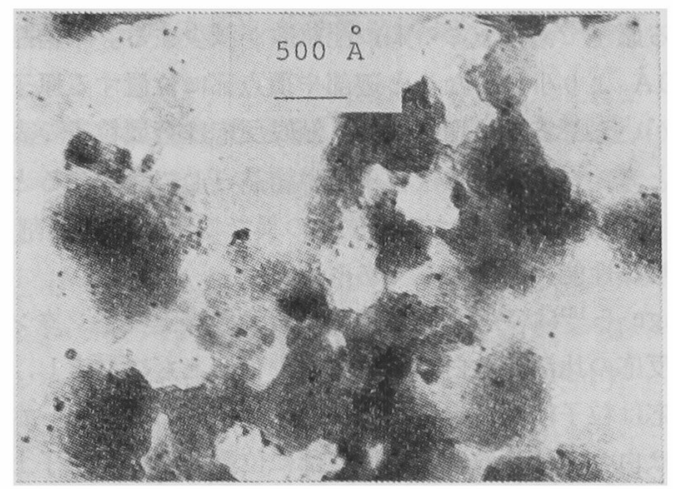

b) $6.89^{\circ} \mathrm{wtz} \mathrm{Rh} / \mathrm{SiO}_{2}$

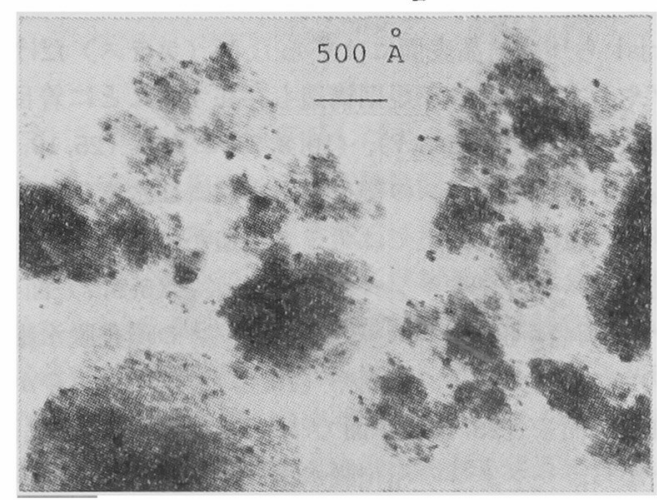

Fig. 3 Transmission electron micrographs of $\mathrm{Rh} / \mathrm{SiO}_{2}$ catalysts reduced in hydrogen at $500^{\circ} \mathrm{C}$

\section{3 結果}

\section{1 触媒中の口ジウムの存在様式}

$450^{\circ} \mathrm{C}$ で 4 時間焼成したあとの触媒中のロジゥムの存在様式を 赤外吸収スペクトルで測定した結果を図 1-a) に示した。図 1-b) には，それを $450^{\circ} \mathrm{C} て ゙ 2$ 時間水素中で還元したあとの触媒の赤外 吸収スペクトルを示してある。また，通常の含浸法で調製した $\mathrm{Rh} / \mathrm{SiO}_{2}$ 触媒の焼成後の赤外吸収スペクトルを, 比較のため図 1-c)に示した。

触媒中のロジウム濃度を変化させたとさ $950 \mathrm{~cm}^{-1}$ と $810 \mathrm{~cm}^{-1}$ の吸収強度の比を図 2 に示した。後に述べるように, $950 \mathrm{~cm}^{-1}$ 
Table 1. Mean particle size and dispersion of $\mathrm{Rh}$ in various $\mathrm{Rh} / \mathrm{SiO}_{2}$ catalysts

Cat. No.

Rh conc. $(\%)$

$\begin{array}{rr}0.34 & 409.2 \\ 1.31 & 243.5 \\ 1.72 & 187.4 \\ 3.04 & 112.5 \\ 6.89 & 71.9\end{array}$

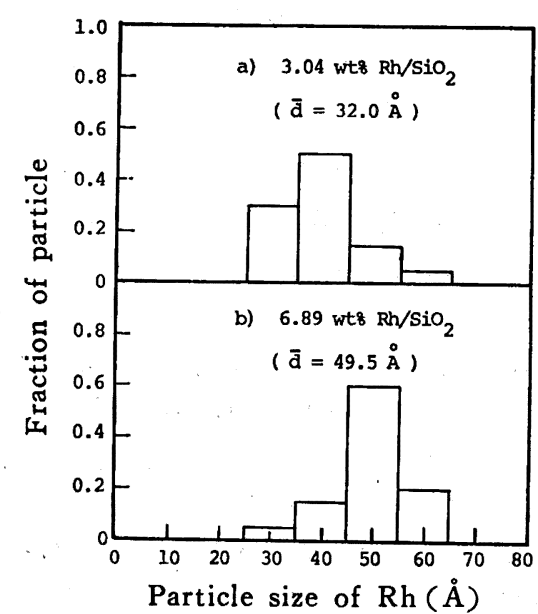

Fig. 4 Particle size distributions of $\mathrm{Rh}$ in $\mathrm{Rh} / \mathrm{SiO}_{2}$ catalysts, prepared by varying the $R h$ concentration from 3.04 to $6.89 \%$ in weight

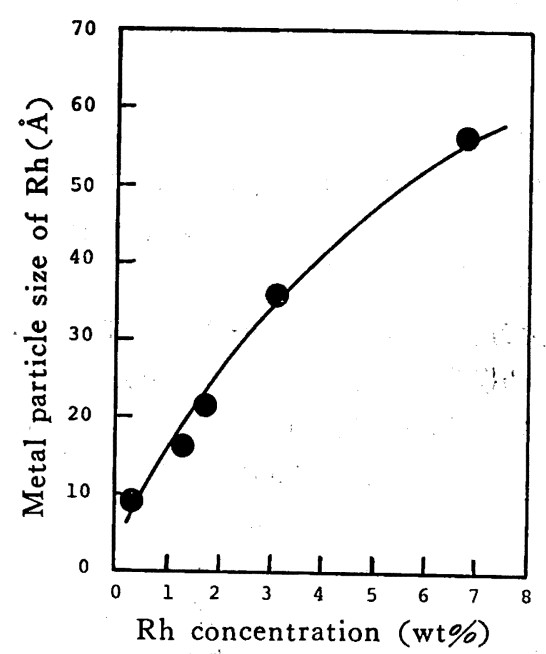

Fig. 5 Change in the metal-particle size of $\mathrm{Rh}$ with its concentration in $\mathrm{Rh} / \mathrm{SiO}_{2}$ catalyst

の吸収ピークは Rh-O-Si 構造の $\nu_{\mathrm{S} 1-\mathrm{o}}$ に帰属されるものであ ク, なた $810 \mathrm{~cm}^{-1}$ の吸収ピークは Si-O-Si 構造の $\nu_{\mathrm{S} 1-0}$ に帰 属されるものであるから, 上述の吸收強度比は $(\mathrm{Rh}-\mathrm{O}-\mathrm{Si}) /(\mathrm{Si}-$ O-Si）に比例すると考えられる。

\section{2 触媒中のロジウム粒子の粒径}

3.04 および $6.89 \mathrm{wt} \% \mathrm{Rh} / \mathrm{SiO}_{2}$ 触媒中のロジウム粒子を透過 型電子顕微鏡で観察した写真をそれぞれ図 3-a）沶よびb) に示 す。これらの写真は 20 万倍の倍率であり，したがって写真中の $1 \mathrm{~mm}$ は $35 \AA$ に相当する。この写真から 300 500 個の粒子の 粒径を測定し, 触媒中のロジウム粒子の粒径分布を求めた。その 結果を図 4-a）およびb) に示した。この粒径分布から単純平均
Mean size ( $\AA$ )

Dispersion (\%) 


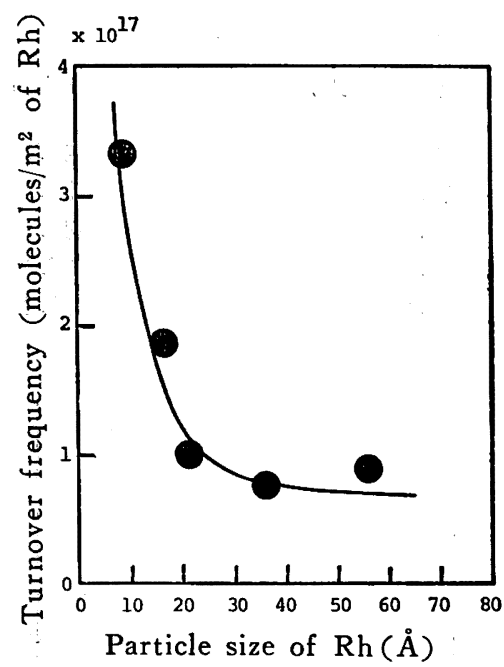

Fig. 8 Relationship between the turnover frequency for decomposition of 1-propanol and the particle size of $\mathrm{Rh}$ in $\mathrm{Rh} / \mathrm{SiO}_{2}$ catalyst

ロジウムを担持した場合には，図 7 に示すようにプロピレンの 生成はをったくみられず, 生成ガスの主成分はエチレン, エタン および一酸化炭素であった。図 6 および図 7 の実験では $\mathrm{SiO}_{2}$ お よび $0.34 \mathrm{wt} \% \mathrm{Rh} / \mathrm{SiO}_{2}$ 触媒 $0.3 \mathrm{~g}$ を用い, 反応温度 $300^{\circ} \mathrm{C}$ で 行なった。図 7 の実験から生成した一酸化炭素の量はエチレンと エタンの生成量の和にほぼ等しいことがわかった。そこで, 生成 する一酸化炭素の量から反応速度を求め, これを各濃度の $\mathrm{Rh} /$ $\mathrm{SiO}_{2}$ 触媒上に物ける turnover frequency に換算した。このよ うにして求めた turnover frequency の值と触媒上のロジゥム粒 子径との関係を図 8 に示した。

\section{4 考察}

触媒上の金属粒子径と反応活性を研究するには，触媒中に反応 の進行に関与する不純物が含有されないこと，金属粒子径の粒径 が比較的均一であることなどが要求される。通常, 容易に入手で きる市販のシリカ担体はとの製造過程で炭酸ナトリウムなどを沈 殿剤として使用しているため，ナトリウムなどの不純物が含まれ る。ケイ酸テトラェチルなどのアルコキシドの加水分解から得ら れる酸化物は比較的高純度であるといわれている。一方, シリカ などの担体に担持する金属についても各種の金属アルコキシドが 市販されているが，これらの金属アルコキシドは通常，金属塩化 物を過剩のアルコール類やベンゼンなどの炭化水素の存在下で, ナトリウムアルコキシドと反応させて調製されており ${ }^{19)}$ ，ナトリ ウムや塩化物イオンが不純物として含まれている。これらの不純 物を完全に除去することは難しい。最近, アルミニウム $=S$-ブト キシドと酶酸ニッケルの混合液から，高分散 $\mathrm{Ni} / \mathrm{Al}_{2} \mathrm{O}_{3}$ 触媒を製 造したことが報告された20)。

本研究では, 各種の金属硝酸塩はエチレングリコールと反応し

19) D. Bradley, R. Mehrotra, D. Gauer, "Metal Alkoxides", Academic Press, New York (1978) p. 180.

20) M. Astier, A. Bertrand, D. Bianchi, A. Chenard, G. E. E. Gardes, G. Pajonk, M. B. Taghavi, S. J. Teichner, B. L. Villemin, "Preparation of Catalysts", edt., B. Delmon, P.A. Jacobs, G. Poncelot, Elsevier, Amsterdam (1976) p. 315.
て，金属のエチレングリコラートを生成するという報告 ${ }^{21)}$ に基づ き，硝酸ロジウムを $80^{\circ} \mathrm{C}$ でエチレングリコールに溶解しロジウ ムのエチレングリコラートを調製した。この物質の単離同定はで

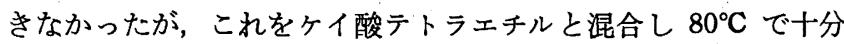
に反応させ加水分解により得られたゲルを乾燥, 焼成した試料中 には Rh-O-Si 構造が生成していた。このことから次式で示され るよらな反応が進行していると思われる。

$$
\begin{aligned}
& 2\left(\mathrm{C}_{2} \mathrm{H}_{5} \mathrm{O}\right)_{4} \mathrm{Si}+\left(\mathrm{CH}_{2} \mathrm{O}\right)_{2} \mathrm{Rh} \longrightarrow \\
& \left(\mathrm{C}_{2} \mathrm{H}_{5} \mathrm{O}\right)_{3} \mathrm{Si}-\mathrm{O}-\mathrm{Rh}-\mathrm{O}-\mathrm{Si}\left(\mathrm{C}_{2} \mathrm{H}_{5} \mathrm{O}\right)_{3} \\
& +\left(\mathrm{C}_{2} \mathrm{H}_{5} \mathrm{OCH}\right)_{2}
\end{aligned}
$$

この種の液相反応の詳細は Bradley ら ${ }^{19)} に よ り$ 報告されてい るが，M-O-Si 構造の存在は赤外吸収スペクトルにより同定され る。シリカ中の O-Si-O 構造には $1100 \mathrm{~cm}^{-1}$ 近辺に这対称伸縮 振動による吸収帯が，また $810 \mathrm{~cm}^{-1}$ 近辺に対称伸縮振動による 吸収帯が現われるが，いずれかの酸素原子が他の金属原子と結合 を生成すると，すなわち M-O-Si(-O) 構造が生成すると，O$\mathrm{Si}-\mathrm{O}$ 構造の逆対称伸縮モードに与える効果が大きく，その吸収 帯が若干低波数側にシフトする現象が見いたされている。たとえ ば Al-O-Si(-O) 構造では $1050 \mathrm{~cm}^{-1} K^{22)}, \mathrm{Zr}-\mathrm{O}-\mathrm{Si}(-\mathrm{O})$ 構造 では $1018 \mathrm{~cm}^{-1} \gtrless^{28)}$ ，また Ti-O-Si(-O) 構造では $920 \mathrm{~cm}^{-1}$ に28)までシフトする。 $\mathrm{Ni}-\mathrm{O}-\mathrm{Si}(-\mathrm{O})$ 構造でも $975 \mathrm{~cm}^{-1}$ にシフ トしていることが報告されている17)。

以上のことから，本研究で見いだされた $950 \mathrm{~cm}^{-1}$ の吸収帯は， 触媒調製過程で生成された $\mathrm{Rh}-\mathrm{O}-\mathrm{Si}$ 棈造に由来するものと結論 した。この構造の濃度は直線的ではないが，触媒中のロジウム濃 度の增加とともに增大していることが図 2 から確認できた。この よらに, アルコキシド法で調製した触媒は，その焼成過程後にお いてもロジウム原子は $\mathrm{Rh}-\mathrm{O}-\mathrm{Si}$ 構造を形成して $\mathrm{SiO}_{2}$ 担体中に ほぼ原子状で分散しているものと考えられ，これが大きな特徴の 一つになっている24)。

水素気流中で還元するとこの $\mathrm{Rh}-\mathrm{O}-\mathrm{Si}$ 構造中の酸素原子が取 り除かれるため構造は崩壊し，ロジゥム（０）原子が生成する。焼 成後においてはシリカ担体中にほぼ均一に原子状分散していたの であるから，還元により生成するロジウム（0)原子の数はシリカ 担体の単位体積あたり，どこでも均一になっているはずである。 これらのロジゥム $(0)$ 原子は熱拡散するが, その程度は還元温度 により決められる。したがって，一定温度で還元すればシリカ担 体の単位体積あたりに生成するロジウム $(0)$ 原子の数、すなわち 本研究の場合は触媒中のロジウム濃度により，金属ロジゥム粒子 の粒径がほぼ均一な大きさで制御されるはずである。図 3 の顕微 鏡写真や図 4 の粒径分布はロジウム粒子の粒径がほぼ均一である ことを示しているし，また図 5 の平均粒子径は触媒中のロジウム

21）依田蜸太郎，木本和幸，戸田卓男，工化，67，909(1964)。

22) K. A. Andrianov, "Polymer Reviews", Interscience, London, (1965) vol. 6.

23) V. A.Zeitler, C. A. Brown, J. Phys. Chem., 61, 1174 (1957); 野上正行, 守屋喜郎, 㝕協, 85, 59(1977).

24）このことは，フルコキシド法で調製した $\mathrm{Ni} / \mathrm{SiO}_{2}$ 触媒で は，その焼成後のニッケル原子はほぼ原子状かあるいは少

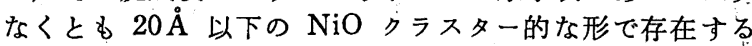
ということが EXAFS により碓認されている25).

25) K. Tohji, Y. Udagawa, S. Tanabe, A. Ueno, J. Am. Chem. Soc., 106, 612(1984). 
濃度により制御可能であることを示している。

なお，図 1 には還元後の試料の赤外吸収スペクトルも示してあ るが還元後においても, 若千の吸収が $950 \mathrm{~cm}^{-1}$ に残存すること から， $450^{\circ} \mathrm{C} ， 2$ 時間水素還元といら条件では還元率は $100 \%$ に はなっていないことがわかった。通常の含浸法で製造された触媒 では，上記の条件で完全に還元されるとされているので，このこ とからもアルコキシド法による触媒調製素過程中では含浸法の場 合と異なった反応が生じていることが示唆される。たたし，還元 率が正確にわからなかったこと, 赤外吸収強度からの試算では $85 \%$ 以上は還元されていると予測されることなとから，水素吸 収法によるロジウム粒子の表面積などの算出は, 便宜上, 完全に 還元されたと仮定して行なった。

以上から, 本研究で製造した $\mathrm{Rh} / \mathrm{SiO}_{2}$ 触媒には触媒作用に大 きな影響を与えると思われる不純物が存在しないこと，また触媒 上のロジウム粒子の粒径もほぼ均一であることが確認できた。そ こで, 本触媒上に拈けるロジウム粒子の粒径が, その触媒性能に どのような効果を有するのかを，1-プロパノールの分解反応をモ デル反応にとりあげ検討した。

1-プロパノールをシリカ上で $300^{\circ} \mathrm{C}$ で反応させると脱水反応の みが進行し，多量のプロピレンが生成する（図 6)。しかしロジ ウムを担持した触媒ではプロピレンの生成がみられず，一酸化炭 素とエチレン，エタンがおるに生成される。(Gobal ${ }^{26)}$ む $\mathrm{ZnO}$ 上 でのェタノールの分解では脱水反応のみが進行し, ェチレンのみ が生成されるが, $\mathrm{Rh} / \mathrm{ZnO}$ 触媒ではアルデヒド, メタン, 一酸化 炭素が主生成物になると報告している。したがって， $\mathrm{Rh} / \mathrm{ZnO}$ 触 媒上では,

$$
\mathrm{C}_{2} \mathrm{H}_{5} \mathrm{OH}(\mathrm{g}) \longrightarrow \mathrm{CH}_{3} \mathrm{CHO}(\text { ads }) \longrightarrow \mathrm{CO}(\mathrm{g})+\mathrm{CH}_{4}(\mathrm{~g})
$$

のように吸着アルデヒドを反応中間体として進行していると考え られる。本実験の場合にも1-プロパノールは次式で示すように吸 着プロピオンアルデヒドを反応中間体として進行しているのであ ろう。

$$
\begin{aligned}
& \mathrm{CH}_{3} \mathrm{CH}_{2} \mathrm{CH}_{2} \mathrm{OH}(\mathrm{g}) \longrightarrow \mathrm{CH}_{3} \mathrm{CH}_{2} \mathrm{CHO} \text { (ads) } \longrightarrow \\
& \mathrm{C}_{2} \mathrm{H}_{4}(\mathrm{~g})+\mathrm{CO}(\mathrm{g})
\end{aligned}
$$

生成したエチレンの一部は水素化されてェタンとなるが, 図 7 か らわかるようにェチレンとェタンの生成量の和は，一酸化炭素の 生成量とほぼ等しい。そこで，本反応の反応速度は一酸化炭素の 生成量から求めた。図8にはこのよらにして求めた反応速度を口 ジウムの単位表面積あたりの速度に换算したあと, ロジウムの平 均粒子径に対してプロットしてある。これから，ロジゥム粒子径 の減少とともに反応の turnover frequency が増大することが確 認された。ロジウム金属の結晶は面心立方格子を形成するので, 触媒上のロジウム粒子が微単結晶として存在すると考えると, 粒 子径 (結晶径) の增減とともに, 粒子表面に露出しているロジウ 厶原子のうち, 結晶の辺部や頂点部に存在する原子の割合は図 9 のように変化する ${ }^{12) 17) 。 ~}$

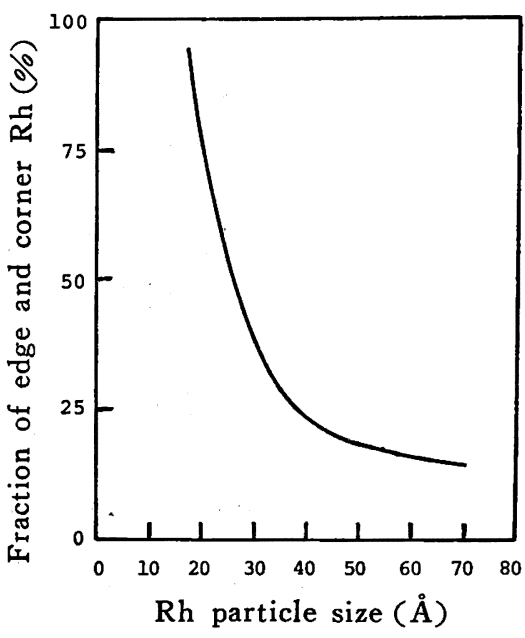

Fig. 9 Fraction of the $\mathrm{Rh}$ atoms located on the edges and corners of $\mathrm{Rh}$ crystallite (f.c. c. packing) ${ }^{12)}$

図 8 と図 9 とを比較すると粒子径に対するturnover frequency と辺部や頂点部に位置する原子の存在割合の変化のようすがよく 一致する。このことから， $\mathrm{Rh} / \mathrm{SiO}_{2}$ 触媒上に打ける 1-プロパノ 一ルの分解反応は，ロジウム粒子（微結晶）の辺部や頂点部に位 置するロジウム原子上で吸着プロピオンアルデヒドを生成し，分 解反応が進行すると考えられる。

著者らが以前に行なった実験 ${ }^{16) て ゙ は ， フ ゚ ロ ヒ ゚ オ ン ア ル テ ゙ ヒ ト ゙ は ~}$ $\mathrm{Ni} / \mathrm{SiO}_{2}$ 触媒上の ニッケル粒子の辺部や頂点部では水素化されて 1ープロパノールを生成し，粒子の平面部では分解してェチレン， エタンおよび一酸化炭素を生成することがわかっている。ニッケ ル触媒もロジウム触媒も水素化や脱水素に有効な触媒であり，そ の触媒作用に類似する点が多い。したがって，ロジウム粒子の辺 部や頂点部に位置するロジウム原子上で吸着プロピルアルデヒド が生成するとしても，そのまま辺部や頂点部の原子上で分解する とは考えにくい。辺部や頂点部で生成した吸着プロピオンアルデ ヒドは平面部のロジウム原子上に移動してエタン, エチレンおよ び一酸化炭素に分解すると考える方が妥当であろう。すなわち, $\mathrm{Rh} / \mathrm{SiO}_{2}$ 触媒上に拈ける 1-プロパノールの分解反応は

\section{$\mathrm{CH}_{3} \mathrm{CH}_{2} \mathrm{CH}_{2} \mathrm{OH}(\mathrm{g}) \longrightarrow$ \\ $\mathrm{CH}_{3} \mathrm{CH}_{2} \mathrm{CHO}$ (ads. on edge and corner $\mathrm{Rh}$ )}

$\mathrm{CH}_{3} \mathrm{CH}_{2} \mathrm{CHO}$ (ads. on edge and corner $\mathrm{Rh}$ ) $\longrightarrow$ $\mathrm{CH}_{3} \mathrm{CH}_{2} \mathrm{CHO}$ (ads. on surface plane $\mathrm{Rh}$ )

$\mathrm{CH}_{3} \mathrm{CH}_{2} \mathrm{CHO}$ (ads. on surface plane $\left.\mathrm{Rh}\right) \longrightarrow$

$$
\mathrm{C}_{2} \mathrm{H}_{4}(\mathrm{~g})+\mathrm{CO}(\mathrm{g})
$$

にしたがってェチレンや一酸化炭素に分解するむのと思われる。 ロジウム粒子の微粒化にともない(1)の反応が促進され, 吸着プ ロピオンアルデヒドの濃度が增加するため, 全反応でのturnover frequency が増大するのであろう。

26) F. Gobal, J. Chem. Res. (S), 1981, 118. 


\title{
Special Articles on \\ Chemistry of Fine Particles and Applications
}

\author{
Particle-size Control of Rhodium Dispersed on Silica \\ and Its Effects on Decomposition of 1-Propanol \\ Seiji Takasaki**, Fumio Koga***, Syuji Tanabe, \\ Akifumi Ueno* and Yoshihide Kotera \\ Department of Materials Science, Toyohashi University of Technology; \\ Tempaku-cho, Toyohashi-shi 440 Japan \\ ** Present address: Kawaken Fine Chemicals Co.; Imafukunakadai, \\ Kawagoe-shi 356 Japan \\ *** Present address: Ryokakogyo Co.; Hiroe, Krashịi-shi 712 Japan
}

The techniques to control metal-particle size were investigated by using tetraethyl silicate and rhodium nitrate dissolved in ethylene glycol. The particles in the reduced catalyst were in an even size level, and the mean particle size increased with an increase in the concentration of rhodium in the catalyst, varying from 0.34 to $6.89 \%$ in weight. The effects of metal-particle size on the decomposition of 1-propanol were explained in terms of the fraction of the metal atoms being located at the corners and edges in the metal crystallites. During the decomposition of the alcohol, 1-propanol adsorbed on the corner and edge atoms to form propionaldehyde (ads), and then the adsorbed species moved to rhodium atoms on the surface planes of the crystallites to be decomposed to carbon monoxide and ethylene, since propionaldehyde was decomposed to carbon monoxide and ethylene at the surface plane atoms of nickel crystallites in $\mathrm{Ni} / \mathrm{SiO}_{2}$ catalyst.

Recent studies on the relationship between metal-particle size and its effects on catalytic behavior were also surveyed and discussed in the present communication. 